\title{
Vida de professora: ideias e aventuras de Leolinda de Figueiredo Daltro durante a Primeira República
}

\author{
Elaine Pereira Rocha*
}

Resumo: Durante os últimos anos do Império e durante a Primeira República, o sistema de ensino foi estabelecido como parte do projeto modernizador do Estado. Já de início, evidenciava-se a crescente mobilização de mulheres empregadas como professoras. A professora baiana Leolinda de Figueiredo Daltro foi uma dessas professoras. Parte de uma "baixa classe-média" que se formava no Rio de Janeiro, a professora teve uma vida extremamente rica que ela registrou em escritos autobiográficos, juntamente com testemunhos e ideias sobre a política e a educação. Este artigo apresenta a vida de Leolinda como professora, seus desafios econômicos, sua prática profissional e suas ideias, altamente influenciadas pela filosofia positivista. A trajetória de Leolinda possibilita um exame da vida no Brasil e no Rio de Janeiro entre 1890 e 1930, principalmente, misturando o projeto modernizador e ordenador do Estado, o debate indigenista e as reivindicações das mulheres que deram origem ao movimento feminista brasileiro.

Palavras-chave: educação; feminismo; indigenismo; positivismo.

Abstract: During the last years of the Brazilian Empire and during the First Republic, the Brazilian education system was established as part of the modernization project. Right from the start there was evidence of the growing engagement of women employed as teachers. The Bahian teacher Leolinda Figueiredo Daltro was one of those teachers. Part of a "lower middle class" that was formed in Rio de Janeiro, the teacher had an extremely rich life, which she recorded in autobiographical writings, along with testimonies and ideas about politics and education. This article presents the life of Leolinda as a teacher, the economic challenges that she faced and her professional practice and ideas, highly influenced by the positivist philosophy. The trajectory of Leolinda enables an examination of life in Brazil and Rio de Janeiro between 1890 and 1930, mainly by mixing the modernizing project and attempt to introduce some order in the society by the state, it also includes the indigenous debate and claims of women who gave birth to the Brazilian feminist movement.

Keywords: education; feminism; indigenism; positivism.

* Doutora em História pela Universidade de São Paulo (USP). Coordenadora da área de História da América Latina e chefe do Departamento de História e Filosofia da Universidade de West Indies, Cave Hill Campus, Barbados. 
Nos últimos anos do século XIX uma professora primária ganhava visibilidade nas páginas dos jornais do Rio de Janeiro, e por vezes de São Paulo, ao apresentarse como voluntária no projeto positivista de civilização dos índios selvagens. Dona Leolinda de Figueiredo Daltro (1858-1935) moveu opiniões na capital federal ao recusar-se ao papel de sujeito coadjuvante ou simplesmente figurante relegado à mulher naquele período.

A biografia da professora, baseada em escritos autobiográficos, coleções de documentos organizados pela própria e publicações motivadas por objetivos políticos, além de documentação oficial e da literatura histórica sobre o período, transita entre a história das mulheres e a história política do Brasil na Primeira República. Este estudo, porém, visa inserir a experiência profissional de Dona Leolinda numa história do trabalho, discutindo sua trajetória, suas perspectivas e desafios numa vida dedicada ao ensino.

A proposta de um estudo sobre a vida de uma professora brasileira a ser incluída num dossiê sobre o trabalho baseado em biografias tem como intuito extrapolar as abordagens sobre a feminização do ensino no Brasil durante a segunda metade do século XIX - ainda que esta esteja presente na trajetória de Leolinda para discutir as ideias de uma mulher pertencente a uma nascente classe média brasileira sobre as novas ideias positivistas e a proposta daqueles intelectuais e políticos para o papel das mulheres na nova ordem republicana.

Desde os anos 1970, o desenvolvimento de uma área importante da historiografia denominada História das Mulheres veio atender à necessidade de contrapor o discurso misógino da história tradicional e mesmo das chamadas "novas histórias". A história do trabalho e do movimento trabalhista foi uma das categorias criticadas por não abranger uma análise sobre o papel das mulheres e das relações de gênero. Johan Scott, ${ }^{2}$ por exemplo, condenou o trabalho de Edward Thompson, A formação da classe operária inglesa, ${ }^{3}$ apontando para o papel marginal que o historiador relegou às mulheres em sua obra sobre o movimento operário na Inglaterra.

Da mesma forma, na corrente das reformulações teóricas do pós-colonialismo, feministas marxistas criticaram, nas últimas décadas do século XX, a negligência marxista quanto ao trabalho feminino, uma vez que, por definição, o trabalho era tradicionalmente considerado como a atividade dos que não possuem os meios de produção, mas por meio de seu esforço físico produzem a mais valia. Nesse caso, o trabalho das mulheres nas lavouras familiares, nas hortas e pomares, na coleta de alimentos, pesca e criação de animais domésticos, além do cuidado com os filhos, os idosos e os enfermos, além dos afazeres domésticos em geral, não eram considerados como trabalho, levando a população feminina fora do ambiente capitalista de trabalho à posição de "alienadas" do sistema produtivo.

Ao alienar grande parte da população feminina da classe trabalhadora, esta teoria simplesmente ignora o óbvio, como bem defendeu Martín Paradelo Núñes:

1 Este artigo baseia-se primordialmente em pesquisa elaborada durante meus estudos para obtenção do título de doutora em História Social pela USP, reunidos em tese final sob o título: "Entre a Pena e a Espada. A Trajetória de Leolinda Daltro: 1859-1934”. (Tese de doutorado em História, Universidade de São Paulo, 2002).

2 SCOTT, Johan. "Women in the making of the English working class". In: history. New York: Columbia University Press, 1999, p.68-92.

3 THOMPSON, E. P. A formação da classe operária inglesa I - A árvore da liberdade. $3^{\text {a }}$ edição. Rio de Janeiro: Paz e Terra, 1997. 
Pode parecer de uma evidência simples, notória e palpável, afirmar que a mulher trabalha. Também que a mulher sempre trabalhou. Mas se perguntamos a uma importantíssima massa de gente, não necessariamente vinculada a uma ideologia especialmente reacionária, ou se revemos milhares de páginas de escritos de carácter histórico, independentemente do seu grau de academicismo e de militantismo, semelharia até difícil suster esta afirmação. ${ }^{4}$

Da mesma forma, o trabalho como professora não foi incluído entre as categorias que se dedicaram aos estudos das mulheres na classe trabalhadora, dedicadas inicialmente às mulheres no ambiente das fábricas passando a incluir as mulheres camponesas nos últimos anos. ${ }^{5}$ Os estudos sobre as professoras na história da educação ${ }^{6}$ do Brasil vêm se desenvolvendo como parte dos estudos de história de gênero e história da mulher, provavelmente pelo fato de não se ver a educação como produção de mais valia, portanto fora das classificações marxistas.

Alguns estudiosos das relações de gênero falam em uma "memória feminina", enfatizando que o modo feminino de relembrar e de contar a história se constrói de maneira diversa do modo masculino, que enfatiza o subjetivo em detrimento da objetividade necessária nas análises das lutas de classe ou das dinâmicas políticas. Além disso, a pressão da lógica masculina no rememorar e narrar fatos do passado, segundo os mesmos, influencia a construção e a transmissão da "memória feminina", deixando que a sua forma mais insubordinada apenas se revele em ocasiões especiais ou nas entrelinhas das narrativas. ${ }^{7}$ O campo farto das indagações levou à ampliação das metodologias de pesquisa e do referencial teórico; uma necessidade fremente, quando se tratava de desmentir a chamada ausência de fontes e desconstruir a invisibilidade feminina a partir da releitura dos documentos.

Parte dessa releitura passou pela retomada da biografia de personagens que comporiam essa nova história; assim, a biografia foi uma importante fonte para a reconstrução das trajetórias femininas, já que as experiências individuais de determinadas mulheres poderiam refletir circunstâncias, condicionamentos e modelos que interferem na vida das demais mulheres de uma época, tornando tênues os limites entre o público e o privado. ${ }^{8}$ Nesses casos, as memórias e as experiências diretamente relacionadas ao trabalho e às políticas que influenciam as dinâmicas e as perspectivas sobre trabalho são importantes para entender a profissionalização das mulheres educadoras.

Em se tratando de Leolinda de Figueiredo Daltro, o estudo biográfico auxilia o processo de decifrar e questionar como uma mulher pertencente ao escalão mais baixo da classe média foi influenciada pelas propostas políticas e filosóficas

4 NUÑES, Martin P., "Mulher, trabalho e anarquismo". In RAGO, Margareth. Gênero e história: descobrindo historicamente o gênero. Compostela: CNT, 2012 p.8. Disponível em: http://www.cntgaliza.org/files/ rago\%2ogenero\%20e\%2ohistoria\%20web.pdf. Acesso em 17/07/2016.

5 Ver: MATOS, Maria Izilda Santos de. Trama e poder. Trajetória e polêmica em torno da indústria de juta. $2^{a}$ edição. Rio de Janeiro: Sette Letras, 1996; MARTINS, José de Souza. A aparição do demônio na fábrica. São Paulo: Editora 34, 2008; CINELLI, Catiane e JAHN, Elisiane de Fatima. "A constituição de identidades camponesa e feminista no Movimento de Mulheres Camponesas". Revista Espaço Acadêmico, n.11, p.8692, 2011, In: CINELLI, Catiane. "Movimento de mulheres camponesas: 30 anos de história na construção de novas relações”. Revista Grifos, n.34/35, p.37-49, 2013.

6 LOURO, Guacira Lopes. "Mulheres na sala de aula". In: PRIORE, Mary del (org.) História das mulheres no Brasil. São Paulo: Unesp/Contexto, 1997, p. 443-481; LOPES, Eliane Teixeira. "A educação da mulher: a feminização do magistério". Teoria e Educação, n.4, p.22-40, 1991,

7 FENTRESS, James; WICKHAM, Chris. Memória Social. Lisboa: Editorial Teorema, 1992.

8 SOIHET, Rachel. "História das Mulheres". In: CARDOSO, Ciro F. e VAINFAS, Ronaldo (orgs.). Domínios da história: ensaios de teoria e metodologia. Rio de Janeiro: Campus, 1997. 
do positivismo e pôde ir tão longe em defesa de uma causa, ainda que cercada por obstáculos sociais, econômicos e culturais, num tempo em que muitos homens que compartilharam de sonhos semelhantes desistiram pelo caminho.

O nome da professora Leolinda Daltro começou a aparecer com frequência nos jornais do Rio de Janeiro no ano de 1896, associado à presença de um grupo de indígenas oriundos do estado de Goiás que reivindicavam uma audiência com o governo republicano. Em meio a uma sociedade que vivia o ufanismo da construção da nova nação, louvando a figura mítica do indígena como elemento mais puro da nossa brasilidade, ela foi chamada de missionária pelos jornalistas que viam algo de sublime em sua decisão de dedicar-se à "civilização" daqueles índios, recebendo apoio de diferentes segmentos da sociedade carioca, paulista, mineira e de regiões mais distantes da capital onde vivia. Na imprensa carioca seu nome esteve em evidência por aproximadamente 15 anos, o tempo que durou o debate sobre a política indigenista que o Estado brasileiro deveria adotar. Posteriormente, seu nome ressurgiria vez por outra nas páginas dos noticiários em defesa de uma nova causa: o feminismo.

Com seu temperamento intempestivo, teve que lidar com as duras críticas da opinião pública, de políticos e de colegas de magistério que relutavam em aceitar que uma mulher deixasse seu lar e filhos para aventurar-se pelos sertões em companhia de índios e que ousasse retornar e disputar espaço político com os homens. A professora foi, ao longo dos anos, louvada e caricaturada; foi considerada santa, anjo, excêntrica, monomaníaca, visionária, heroína, louca de hospício, doce mãe para filhos e alunos, aproveitadora, herege e anticristo nas palavras de admiradores e desafetos, alguns ilustres como o escritor Lima Barreto. ${ }^{9}$

Muitas dessas opiniões estão registradas em documentos que foram reunidos em sua obra Da catechese dos índios no Brasil: notícias e documentos para a história $^{10}$, uma espécie de livro de memórias onde constam artigos extraídos de jornais, depoimentos e abaixo-assinados de pessoas que testemunharam a atuação de Leolinda em prol dos índios, além das cartas que esta teria recebido nos anos em que esteve nos sertões e de uma cópia de um documento que foi lido pela professora no Primeiro Congresso de Geografia dos Estados Unidos do Brasil, no Rio de Janeiro, em 1909, intitulado "Memória". Ciente de sua importância política e histórica, a professora Leolinda também registrou cópia da ata de fundação do Partido Republicano Feminista (1910), publicado em forma de brochura e de alguns exemplares do jornal A Política, de sua direção ${ }^{11}$, como forma de atestar seu pioneirismo no movimento feminista brasileiro, quando Bertha Lutz foi aclamada a primeira brasileira feminista.

Sua biografia torna-se então mais do que uma simples coletânea de dados sobre a vida de uma pessoa, abrangendo diferentes ângulos de um momento crucial da história do Brasil: a consolidação do governo republicano e a construção da ideia de Nação; a construção de um sistema para a educação pública que é também marcada pela feminização do ensino no Brasil; e as propostas de modernização vinculadas à educação das camadas mais pobres e da civilização dos indígenas, vindo somar a outros trabalhos igualmente importantes sobre esse período

9 LIMA BARRETO. Numa e a Ninfa. São Paulo: Brasiliense, 1956.

10 DALTRO, Leolinda de Figueiredo. Da catechese dos índios no Brasil. Notícias e documentos para a história. Rio de Janeiro: Typographia da Escola Orsina da Fonseca, 1920.

11 A professora publicou mais dois jornais, A Verdade (1902) e A Tribuna Feminina (1916), dos quais foi redatora-proprietária. Infelizmente não foram encontrados exemplares desses periódicos junto aos acervos pesquisados. A facilidade em fazer tais publicações deve-se ao fato de que a escola que fundara com o apoio do poder público possuía uma gráfica, como parte de seu projeto como escola profissionalizante. 
como um outro matiz para essa paisagem em constante movimento. Conforme explica Cristina Borderías:

La biografía se situa así en un lugar intermedio entre lo macrosocial y lo microsocial, el del análisis de las práticas de los indivíduos en cuanto estas evidencian las formas en que éstos se apropian y dan respuesta a las situaciones sociales en que se encuentran. ${ }^{12}$

A intenção deste estudo é apresentar a personagem histórica Leolinda de Figueiredo Daltro como uma mulher inserida nas limitações e polêmicas de seu tempo, não como simples paciente, a sofrer as influências da estrutura e dos acontecimentos que a cercam, mas como alguém atuante, que age e reage em resposta às pressões sociais, econômicas, políticas e culturais de seu tempo, com todas as contradições, limitações e anseios pertinentes à experiência humana, confirmando a hipótese de Joan Scott ${ }^{13}$ que considera nos estudos da 'História das Mulheres' uma condição multifacetada, que extrapola a linearidade, por abordar múltiplos universos dentro de uma mesma experiência ou da experiência de uma coletividade feminina.

Também o historiador Edward Thompson reconheceu a importância da biografia para os estudos históricos sobre a classe trabalhadora:

Apesar de todos os obstáculos, parece inegável que os registros de na-
tureza biográfica nunca deixarão de ser um instrumento essencial ao
trabalho do historiador. Pois nem a abstração numérica das curvas de
preço nem a anatomia impalpável das estruturas mentais de longa dura-
ção adquirem sentido se não forem entendidas como parte das tensões
formadas no conjunto das experiências pessoais dos nossos antepas-
sados. $^{14}$

Leolinda de Figueiredo nasceu em Najé, cidade de Cachoeira, na então província da Bahia, em 14 de julho de 1858: "Ela, a digna filha da Bahia, a descendente de Paraguaçu, primogênita da terra descoberta por Colombo..." ${ }^{15} \mathrm{~A}$ afirmação encontrada e repetida em documentos selecionados pela professora denota a referência ao ancestral indígena tão comum entre os nacionalistas do período, e que servia para afastar qualquer suspeita de sangue negro, explicando a pele mais bronzeada. ${ }^{16}$

Na homenagem feita pelos filhos por ocasião de sua morte, constam os nomes de sua mãe Alexandrina Tupinambá de Figueiredo, e pai, Luiz Antônio de Figueiredo. Ainda que a documentação analisada não indicasse ao certo a filiação racial de Leolinda, um documento encontrado sobre o falecimento de Alexandrina na Freguesia de Maragogipe, em 1861, indica que ela era parda e solteira. ${ }^{17}$ Em que pese a possibilidade de um "embelezamento" sobre seus dados de nascimento, não se pode descartar a possibilidade de uma ascendência indígena, de acordo com Kátia Mattoso em sua análise sobre a população de Salvador por volta de 1870:

12 BORDERÍAS, Cristina. Subjetividad y cambio social en las historias de vida de mujeres: notas sobre el método biográfico. In.: Arenal, Revista de Historia das Mujeres. V. 4, n. 2, julio-diciembre 1997. Granada, Universidad de Granada/Instituto de Estudios de la Mujer, Junta de Andalucia/Consejería de Educación, p.181.

13 SCOTT, Joan. "História das mulheres". In: BURKE, Peter (org.). A escrita da história, novas perspectivas. São Paulo: UNESP, 1992, p.63-96.

14 THOMPSON, Edward P. A miséria da teoria ou um planetário de erros. Rio de Janeiro: Zahar, 1981, p.20.

15 DALTRO, Leolinda. Da catechese dos índios no Brasil, p.282.

16 ROCHA, Elaine P. “Antes índio do que negro”. Dimensões Revista de História da UFES. Vitória, n.18, p.203220, 2006.

17 Livro de óbitos da freguesia de Maragogipe, n.9, fl.48. 
Tais eram os componentes da população de Salvador, cidade colorida e misturada e, por isso, cheia de vida! O processo de 'embranquecimento’ favoreceu o elo obrigatório, representado pela população mestiça. Na Bahia, o ‘branco fino' - ou seja, o português branco - tornou-se cada vez mais uma lembrança histórica; no imaginário o modelo permaneceu europeu, mas a realidade foi marcada por uma miscigenação ainda mais forte do que a sugerida pelas estatísticas. ${ }^{18}$

Devido à dificuldade em se obter documentação oficial sobre a filiação da professora, foram utilizados seus escritos autobiográficos, que se referem a uma infância no meio rural do Recôncavo baiano, aos cuidados da avó e da figura distante do pai, o capitão Luiz Antônio de Figueiredo, que serviu à pátria nos campos do Paraguai. Porém, é preciso enfatizar que um dos riscos da história biográfica, ao se valer de dados autobiográficos e de entrevistas com familiares, como no caso deste estudo, é a construção de um mito familiar, no qual a celebração e a construção e reconfiguração de memórias passam a fazer parte da história de vida do biografado. ${ }^{19}$ Essa reconfiguração de fatos e de origens familiares é, na maioria das vezes, parte de uma política informal de revisar o passado, "consertando" passagens nebulosas ou complementando dados, no sentido de confirmar a importância histórica do biografado.

O fato de que Leolinda era mestiça é definitivamente importante para demonstrar a peculiaridade de sua trajetória, chegando a travar relações pessoais com um dos grandes nomes da Primeira República, Quintino Bocaiúva, e com o marechal Hermes da Fonseca e sua primeira esposa, Dona Orsina da Fonseca. Essas relações foram tão essenciais para os objetivos da professora quanto a construção que esta fez de seu passado como filha de uma índia com um herói da Guerra do Paraguai. O estabelecimento dessa rede de apoio que supera barreiras raciais é dado comum na sociedade brasileira já no século XIX. Ainda conforme Mattoso, na Bahia:

Pessoas de cor se infiltravam por toda parte e viviam em simbiose com uma população branca que incluía europeus e "brancos da terra", cuja pele era apenas um pouco mais clara que a de alguns mulatos. Graças a apoios de família, eles conseguiam ultrapassar a barreira que separava homens livres e escravos. O mais embaraçoso não era ter a pele escura, mas ter antepassados escravos. ${ }^{20}$

A fatalidade da Guerra do Paraguai e as severas restrições econômicas que a situação impunha, principalmente nos meios mais pobres, que poderiam levar crianças como Leolinda a uma situação mais extremada de abandono, acabou por beneficiá-las. Isso porque, a população da Bahia, mais propriamente da cidade de Salvador, mobilizada pelos esforços de guerra, procurou amparar os filhos dos soldados e os órfãos daqueles que perderam suas vidas lutando pelo país. Nesse esforço o papel das mulheres professoras foi fundamental.

Anna Emília Paraíso, Semiana Rosa da Silva Gomes e Rosalina Joanna de Carvalho Matta são alguns nomes de professoras que ofereceram vagas gratuitas em seus estabelecimentos, às vezes em suas próprias casas, para os filhos e

18 MATTOSO, Kátia de Queirós. Bahia, século XIX - uma província no Império. Rio de Janeiro: Nova Fronteira, 1992, p.125.

19 Os dados sobre a paternidade de Leolinda Daltro foram obtidos exclusivamente através das entrevistas com seu neto Othon de Castilho Daltro e da reportagem publicada no Jornal do Brasil, em 5 de novembro de 1948, na coluna "Galeria Nacional", fundamentada nos dados fornecidos por seu filho Leobino de Castilho Daltro.

20 MATTOSO, Bahia, século XIX, p.124. 
filhas de combatentes. Algumas dessas ofertas foram específicas para meninas e previam o ensino em regime de internato para as crianças, configurando-se uma oportunidade única para o desenvolvimento da educação feminina na Bahia. ${ }^{21}$

Muitos soldados enviaram cartas ao governador da província, já a caminho do palco da guerra, solicitando amparo educacional para seus filhos, numa atitude que induz a pensar na troca de informações entre as fileiras, fazendo com que aqueles que haviam partido sem a garantia de amparo e educação para os seus viessem a reivindicá-la mais tarde. ${ }^{22}$ A educação das crianças pode ser considerada como uma espécie de estímulo ao soldado que deveria partir.

Leolinda de Figueiredo foi uma das crianças que se beneficiaram dessa política. Em suas memórias, ela se refere à educação em escola religiosa, enquanto que a sua prática lembra muito a abordagem das freiras Ursulinas que, no último quartel do século XIX, educaram meninas de variada origem social. Durante a pesquisa documental, ainda que sem uma ligação oficial com a biografada, o Colégio das Órfãs do SS. Sagrado Coração de Jesus, em Salvador, sobressaiu-se como uma das instituições de ensino dedicada a alunas órfãs. Como filha de um oficial do Exército que estava lutando na Guerra do Paraguai ${ }^{23}$ e de mãe falecida, Leolinda se enquadrava no grupo assistido pelas religiosas. O colégio educava meninas e as preparava não somente para assumirem as funções de mães e esposas, mas para terem uma profissão, conforme mostra o documento abaixo:

O Colégio das Órfãs do SS. Coração de Jesus tem por fim receber e convenientemente educar meninas órfãs e desvalidas e por isso é reconhecido como Estabelecimento de Caridade.

As educandas deste Colégio concorrem para o desenvolvimento da civilização, pois que a sua educação aperfeiçoada como se acha, não igual à de outra época não muito remota, que não passava dos primeiros rudimentos das escolas e mesquinhos trabalhos de agulha, pouco proveitosos para a obtenção do escasso sustento quotidiano. ${ }^{24}$

No mesmo documento, um pouco adiante, fica clara a preocupação institucional em oferecer às suas alunas uma formação profissional como professora ou meios para sobreviverem de seu trabalho como costureiras, bordadeiras ou floristas, revelava a preocupação das freiras em evitar o desamparo dessas meninas na vida adulta, caso lhes faltasse o marido.

Hoje com o estudo aperfeiçoado e metódico das primeiras letras, do francês, dos princípios elementares de geografia, doutrina cristã, história sagrada, e todas as prendas próprias do sexo, costuras, bordados de linha de prata, de ouro, obras de tear, flores de todas as qualidades..., e com o conhecimento prático dos demais ensinos domésticos a que se dedicam alternadamente no interior do colégio, podem, quando chegam à puberdade e estão no caso de sair... $1^{\circ}$. ganhar decentemente a vida sendo úteis a seus parentes, $2^{\circ}$. ser dignas consortes e boas mães de família, $3^{\circ}$. encarregar-se da educação e instrução de meninas que aprendem em colégios particulares, para onde já se nos tem requisitado nossas educandas... ${ }^{25}$

21 Maço de documentos da Guerra do Paraguai. Arquivo Público do Estado da Bahia (APEB).

22 Maço de documentos da Guerra do Paraguai. APEB.

23 O Livro de Patentes, Guarda Nacional, 1869-1899, parte do acervo do Arquivo Nacional registrou a nomeação do tenente Luiz Antonio Figueiredo a capitão, em 1873, no estado da Bahia.

24 Relatório apresentado à Nova Meza do Collegio das Orphãs do SS Coração de Jesus pelo escrivão do mesmo collegio, Dr. Eloy José Jorge. Bahia, Typographia dos Orphãos de S. Joaquim, 1872. APEB.

25 Relatório apresentado à Nova Meza do Collegio das Orphãs do SS Coração de Jesus pelo escrivão do mesmo collegio, Dr. Eloy José Jorge. Bahia, Typographia dos Orphãos de S. Joaquim, 1872. APEB. 
Dessa forma, estariam buscando uma forma de oferecer àquelas alunas de poucos recursos uma opção de sobrevivência que as afastasse da miséria e do risco da prostituição. A prática de Leolinda como professora e sua visão sobre a educação feminina refletem a influência ursulina em sua formação. Segundo depoimento co-lhido em entrevistas com seus familiares, Leolinda, que teria se casado pela primeira vez aos 15 anos, em 1873, quando já exercia a profissão de professora e, em 1883, teria saído de Salvador com a família para lecionar pelos sertões baianos.

Em 1911, quando fundou sua própria escola para mulheres, no Rio de Janeiro, a professora colocaria em prática os ideais da educação ursulina:

O programa da Escola é difundir o ensino prático de profissões adequadas às mulheres. Ali elas aprendem a fazer chapéus, flores, bordados, cortar seus próprios vestidos e até cortar roupas para seus maridos e filhos. Para isto pagamos um alfaiate que ensina a fazer roupas para homem. ${ }^{26}$

Mas antes de analisarmos a trajetória de Leolinda no campo da educação, convém apresentar brevemente o processo pelo qual a educação pública se desenvolveu no Brasil e, em consequência, as mulheres entraram no campo de trabalho do magistério.

Já nos últimos anos do Império, o governo brasileiro empenhava-se na tarefa de modernizar o país, um projeto que se iniciara em meados do século, mas cujas mudanças na economia e na sociedade mundial impeliam o Brasil a adaptar-se às novas demandas. E foi principalmente a partir do final da Guerra do Paraguai que se verificou a ampliação da malha ferroviária, o novo impulso da economia cafeeira e o desenvolvimento urbano que criava uma classe média no país, dedicada ao comércio, aos serviços e às pequenas indústrias. Esse desenvolvimento estimulava a criação de escolas para educação primária, direcionadas para o ensino de ambos os sexos, uma vez que as mesmas necessidades impunham a incorporação das mulheres em novos trabalhos, sobretudo na indústria nascente.

Em 1875, durante debate na Câmara dos Deputados, o ensino profissionalizante é defendido por Cunha Figueiredo Jr., que pela primeira vez faz referência à profissionalização de mulheres: "... Ao trabalho profissional podem aplicar-se as mulheres que deles necessitam, visto que há nas fábricas, oficinas e estabelecimentos onde elas exerçam diversos ofícios e misteres, sem ser necessária a criação de escolas com aumento da despesa pública". ${ }^{27}$ Essa atitude dos poderes públicos em relação à formação das mulheres para o trabalho reflete o discurso preponderante acerca das funções femininas, que permaneceu durante décadas, chegando a meados do século XX, segundo o qual as tarefas executadas pelas muIheres, mesmo na indústria, assemelhavam-se às tarefas executadas no trabalho doméstico.

Outros trabalhos considerados mais adequados à natureza feminina estavam ligados à culinária (doces e quitutes), à costura e bordado e aos serviços domésticos em geral, que faziam parte da formação de uma boa moça e poderiam ser inseridos nos currículos como prendas domésticas. Quanto ao trabalho agrícola, uma preocupação da época, as mulheres eram consideradas apenas como mão de

26 Evocando os primeiros surtos do feminismo. Entrevista de Leolinda de Figueiredo Daltro ao jornal A Noite. $\mathrm{O}$ trecho selecionado fala na Escola Orsina Fonseca, criada como Escola de Sciencias Artes e Profissões, em 1911, para atender principalmente ao sexo feminino. A Noite, Rio de Janeiro, 3 ago. 1934.

27 MOACYR, Primitivo. A instrução e o Império - Subsídios para a história da educação no Brasil. São Paulo: Companhia Editora Nacional, 1937, v.2, p.158. 
obra complementar ou auxiliar, não carecendo de qualquer instrução técnica para executá-lo. ${ }^{28}$

Se nos projetos oficiais de educação as mulheres foram descartadas enquanto clientela para cursos profissionalizantes, elas acabaram se impondo, pouco a pouco, como professoras primárias, em virtude da escassez de professores. Surgia uma nova oportunidade profissional para as mulheres: o professorado, visto como uma atividade para a qual a mulher teria uma inclinação natural, posto que seria um desdobramento de sua função maternal, educar crianças. ${ }^{29}$

O número de mulheres que se empregavam nessa profissão rapidamente cresceu, assim como o número de meninas matriculadas nas escolas primárias que, em 1872, merecia destaque no relatório oficial da Corte, o qual dava conta da existência de 110 estabelecimentos frequentados por 39.000 alunos e 2.249 alunas. ${ }^{30}$ No final do século XIX, as mulheres constituíam um terço dos professores no Rio de Janeiro em 1872, sendo que a lista nominal de professores, que teria servido como base para os pagamentos no Distrito Federal para aquele ano, registra 99 professores do sexo masculino, contra 350 do sexo feminino. ${ }^{31}$

Essa feminização do magistério deu-se em razão dos baixos salários, que tornavam a função pouco atrativa para os homens. No final do século, muitos políticos queixavam-se da falta de professores para ministrar aulas para meninos em disciplinas consideradas avançadas como cálculo e geometria analítica - disciplinas vetadas nos currículos dirigidos à clientela feminina do curso normal, sob o argumento de que essas eram portadoras de uma limitação natural ao aprendizado das ciências exatas ${ }^{32}$ - enquanto mulheres protestavam o direito de obterem, em sua formação, o acesso a essas disciplinas. Os documentos examinados mostram variadas estratégias das mulheres para melhorar sua própria educação, ressaltando-se o pretexto de que estavam ensinando a meninos e, portanto deveriam ter acesso ao currículo que deveria ser ensinado aos estudantes masculinos. Houve também professoras que foram reportadas pelos inspetores por estarem ensinando a estudantes femininas conteúdos reservados aos meninos. Nesse caso, as professoras alegaram que: não dispunham de espaço físico na sala de aula para separar meninos e meninas; que não dispunham do material necessário para o trabalho de agulhas (linhas, agulhas e tecido) e, portanto, tinham que ensinar as disciplinas clássicas; que não queriam expor as meninas ou os meninos às intempéries climáticas deixando um grupo do lado de fora da sala enquanto ensinavam a outro. Com tais subterfúgios, pouco a pouco, as professoras foram quebrando as barreiras de gênero do ensino.

Em diferentes regiões do país, grande parte das mulheres que apresentavam requerimento apresentando-se para o cargo de professora traziam como referências a sua formação e a experiência anterior, muitas vezes lecionando de forma particular, em sua própria casa, o que demonstra uma atividade de ensino mantida paralelamente aos registros oficiais. ${ }^{33}$ Conforme pode-se ver abaixo, esta situação não diferia entre os diferentes estados:

28 METCALF, Alida C. Family and frontier in colonial Brazil - Santana de Parnaíba, 1580-1882. Oxford: University of California, 1992.

29 A feminização do magistério na segunda metade do século XIX, de fato, já vinha avançando em diferentes pontos do país, conforme destacou LOPES em "A educação da mulher: a feminização do magistério".

30 MOACYR. A instrução e o Império, p.158-160.

31 Arquivo Geral da Cidade do Rio de Janeiro, Livro de Instrução Pública. Docentes, 1896-99.

32 LOURO, Guacira Lopes. "Mulheres na sala de aula".

33 Dados confirmados por documentação encontrada no Arquivo Público do Estado da Bahia. Documentos da Guerra do Paraguai. 
08 de novembro de 1882

IImos. Senhores Presidente e mais vereadores da Ilustríssima Câmara Municipal da Corte (...)

Fellipa Izabel S. de Freitas, casada doc 1, no gozo de perfeita saúde doc 2, mãe de família exemplar doc 3, com exame público para o magistério primário doc 4, exercendo-o particularmente a mais de 2 anos, desejava (se Vossas Excelências o permitirem) inscrever-se ao concurso de professora para quaisquer das cadeiras vagas das escolas municipais. (...)

A suplicante autorizada por seu marido doc 5, pede respeitosamente a Vossas Excelências a graça de aceitando... ${ }^{34}$

Os "doc", citados na correspondência são documentos que acompanham o requerimento, os quais cumprem a função de comprovar seu estado civil, seu estado de saúde, a maternidade, a habilitação como professora e a autorização do marido para que a esposa trabalhe, sendo todos documentos exigidos pela lei vigente. Ao que parece, também Leolinda teria se submetido ao mesmo processo ao empregar-se como professora.

Em seus relatos, ela conta que chegou ao Rio de Janeiro em 1887 empregando-se como professora de escola pública, valendo-se de sua experiência profissional na Bahia à qual certamente somou-se a influência de uma rede de contatos e amigos bem relacionados junto ao governo imperial. ${ }^{35} \mathrm{~A}$ professora afirmava que seu programa educacional apresentou-se à sociedade carioca como inovador, pela inclusão de aulas de ginástica e de formação para o trabalho, iniciativas apreciadas por autoridades do governo imperial e pelo casal Conde D'Eu e Princesa Isabel.

O programa primário era, naquela época, por demais deficiente; o ensino limitava-se à leitura, escrita, gramática e às quatro operações fundamentais da aritmética.

Achei que isso era pouco e que eu podia, como professora, ampliá-lo, o que fiz, inaugurando um novo regime escolar. Iniciei, portanto, o ensino de ARTES E PROFISSÕES, de que o programa oficial não cogitava, de forma que as crianças cursassem, além das matérias do programa oficial, mais outras, facultando-lhes assim aptidões necessárias a fim de que, ao saírem da escola, pudessem obter, com o trabalho, os meios de subsistência. ${ }^{36}$

Considerada como outra inovação na educação, a formação profissionalizante surgiu na época como uma preocupação vinculada à educação para trabaIhadores, isto é, a abertura de cursos noturnos que viessem a atender à demanda de alunos que trabalhavam durante o dia. A maior parte desses cursos era iniciativa dos próprios professores que, percebendo demanda existente, solicitavam permissão a seus superiores para criarem cursos direcionados a uma clientela já definida, como se pode verificar pelo trecho do requerimento de 8 de junho de 1881: "O professor Augusto Arthur de Siqueira Amazonas pede licença à Ilma. Câmara para, na Escola São Sebastião, abrir um curso noturno para adultos."37

No município do Rio de Janeiro, entre 1872 e 1889, o número de cursos noturnos cresceu a ponto de justificar registros especiais na Secretaria de Instrução

34 Instrução Pública. Livro 11-4-10, fl.286. Arquivo Geral da Cidade do Rio de Janeiro.

35 Entre os grandes amigos de Leolinda encontramos nomes como Quintino Bocaiúva, José do Patrocínio e outros intelectuais reconhecidos da época.

36 DALTRO, Leolinda de Figueiredo. Inícios do feminismo no Brasil. Subsídios para a história. Rio de Janeiro: Typ. da Escola Orsina da Fonseca, 1918, p.4.

37 Instrução Pública. Livro 11-4-10, fl.167. Arquivo Geral da Cidade do Rio de Janeiro. 
Pública. Surgiram instituições filantrópicas de ensino destinadas à população trabalhadora, como a "Escola do Povo", fundada em 1881 pelos professores Antonio Augusto Maia Maciel e Carlos Augusto Moreira da Silva, que oferecia educação gratuita para adultos. ${ }^{38}$ Em alguns casos, o próprio governo reconhecia, os cursos eram mantidos à custa dos professores, que além de não receberem pagamentos por aulas extras, pagavam do próprio bolso o querosene para os lampiões a gás. ${ }^{39}$

Percebe-se, na leitura de tais ofícios e requerimentos, que professores e professoras viam-se engajados num projeto educacional que era concebido quase como um sacerdócio, já que o trabalho extrapolava as fronteiras do profissionalismo e aproximava-se do conceito de missão. Na época, Leolinda abriu turmas para aulas noturnas, visando atender estudantes que trabalhavam durante o dia.

Pelo meu grande amor à instrução, mantive um CURSO NOTURNO GRATUITO, no edifício do Matadouro de Santa Cruz, durante todo o tempo em que lá estive. Esse meu ato foi motivado pela piedade que eu tinha das crianças, impedidas de frequentar as aulas diurnas, por terem de ajudar os pais no serviço do Matadouro. ${ }^{40}$

A existência de uma lei que determinava a obrigatoriedade do ensino e ensino noturno para jovens trabalhadores oferecia o respaldo para a reivindicação desses professores. Dessa forma, eles estavam ativamente engajados na ampliação da oferta da educação, mesmo que isso significasse alterar os horários das aulas ou mesmo a mudança dos prédios escolares para locais próximos a uma concentração de trabalhadores.

Em alguns casos, a própria população reivindicava a existência de uma escola ou de curso noturno, e o reconhecimento governamental poderia não acontecer tão prontamente, como recorda Leolinda em seu discurso:

Transferida ainda por conveniência do ensino, e ainda por meio de dois - ABAIXO ASSIGNADOS - para a Praia Pequena, continuei com o CURSO NOCTURNO, no qual se matricularam sessenta e quatro operárias da - FABRICA DE PHOSPHOROS CRUZEIRO, - tendo eu a felicidade de ensinar e educar pobres moças analfabetas, das quais, duas hoje são professoras catedráticas, algumas floristas, modistas, etc. Esses cursos foram mantidos GRATUITAMENTE, fora do programa oficial e por minha própria conta...

As transferências de uma escola à outra, conforme se constata na documentação, muitas vezes partiam de pedidos pessoais de professoras que se propunham a trocar de escola, por meio de permuta, por conveniências familiares, como por exemplo, quando a escola oferecia moradia para a professora e sua família. Fator que parece ter sido importante nas transferências.

Note-se que o empenho de Leolinda em prol da educação é aqui ressaltado pela própria, como uma atitude voltada para o atendimento a uma reivindicação popular, e que ela considerava que seu esforço não havia sido em vão, pelo fato de ter conseguido não apenas alfabetizar suas alunas mas prepará-las para o exercício profissional, fora da fábrica. Na época em que esse discurso era feito, a imprensa

38 Instrução Pública. Livro 15.3.4, fl.37.

39 Instrução Pública. Livro 15.3.4, fl.37.

40 DALTRO, Inícios do feminismo no Brasil, p.5. Destaque da autora.

41 DALTRO, Inícios do feminismo no Brasil, p.6. Destaque da autora. 
já veiculava um debate sobre o trabalho fabril para mulheres - tanto quanto o de crianças - considerado impróprio e degradante por alguns setores. ${ }^{42}$

Durante os primeiros anos da República, os problemas econômicos e sociais se ampliavam, ${ }^{43}$ exigindo medidas políticas e administrativas nas grandes cidades como o Rio de Janeiro, cuja população se multiplicava a cada dia, sujeita à carestia, ao desemprego, às epidemias. ${ }^{44}$

Nesse momento, Leolinda já estava casada pela segunda vez, passando a se chamar Leolinda de Figueiredo Daltro. Seu marido, Apollonio, era funcionário da Fazenda, e ela, professora do Distrito Federal; eram ambos funcionários públicos. Como professora, Leolinda estava exposta aos atrasos no pagamento, que deixou ela e sua família numa situação vulnerável diante dos problemas enfrentados pela população carioca no início do período republicano. Nessa época, a professora valeu-se de um expediente comum no período, de residir no mesmo prédio em que ministrava aulas. Dessa maneira, a família mantinha-se ao abrigo dos altos aluguéis cobrados na capital, mas não escapou das epidemias. Por essa época, a professora teria perdido um de seus filhos, ${ }^{45}$ que faleceu antes de completar um ano de idade, vítima de uma das muitas febres que dizimavam anualmente a população carioca. ${ }^{46}$

Por outro lado, o empenho dos professores no projeto de instrução oficial, indo além das expectativas governamentais, manteve-se na transição para a República, e foi estimulado pelos positivistas, que reconheciam em seus princípios a importância da educação como instrumento de civilização, não apenas dos selvagens, mas do povo em geral. ${ }^{47}$

Com base nisso, levanta-se a hipótese de que os professores tenham sido uma categoria essencialmente útil ao governo republicano que se formava, ao propagarem as ideias desse governo e de contribuir para a sua aceitação, por meio da exaltação aos valores nacionais e do apoio oferecido a um modelo de governo forte e autoritário que conduzisse o país ao progresso. Propõe-se que os professores, uma vez convencidos pelo discurso positivista dos intelectuais daquele momento, tenham empenhado seus esforços no sentido de educar jovens e crianças dentro da proposta então considerada como científica e modernizadora, e que era expressa nos programas de ensino e em diferentes publicações abertas ao público. Jorge Nagle refere-se a um "fervor ideológico" que, vindo das décadas finais do Império, vai se manifestar nos primeiros anos da República. ${ }^{4}$

Leolinda Daltro enfatiza com orgulho seu empenho e entusiasmo em participar de cultos aos heróis nacionais, como Tiradentes, e da celebração das datas

42 MATOS. Trama e Poder.

43 A crise financeira do país tinha múltiplas causas como a crise da borracha, a decadência da produção açucareira no Nordeste, além das oscilações no preço do café no mercado externo. Medidas administrativas tinham como objetivo atender às demandas relacionadas ao problema econômico e ao grande crescimento demográfico em cidades como o Rio de Janeiro. FAUSTO, Boris. História Concisa do Brasil. São Paulo: Edusp/Imprensa Oficial do Estado, 2001.

44 José Murilo de Carvalho fala sobre problemas de habitação, de abastecimento de água, de saneamento e de higiene, agravados com o mais violento surto de epidemias da história da cidade. Doenças como varíola e febre amarela somaram-se à malária e tuberculose. CARVALHO, José Murilo de. Os Bestializados - O Rio de Janeiro e a República que não foi. São Paulo: Companhia das Letras, 1987, p.18-19.

45 Conforme entrevista de Othon de Castilho Daltro (set./1999), a criança teria recebido o nome de Manoel, morrendo antes de completar um ano de idade após constatar-se uma súbita febre.

46 CHALHOUB, Sidney. Cidade febril: cortiços e epidemias na Corte imperial. São Paulo: Companhia das Letras, 1996.

47 SALLES.

48 NAGLE, Jorge. “A educação na Primeira República”. In FAUSTO, Boris (org). O Brasil Republicano. 2 - Sociedade e instituições (1889-1930). $5^{\text {a }}$ edição. Rio de Janeiro: Bertrand, 1997, p.259-292. 
históricas, como a Independência e a Proclamação da República. Os alunos e alunas da professora, entre os quais contavam os seus próprios filhos, participavam ativamente das atividades e manifestações públicas de civismo como desfiles e homenagens a políticos célebres. ${ }^{49}$

Essa exaltação à Pátria foi cultivada de maneira exemplar pelo Estado e instituições nos primeiros anos da República, quando o sentimento de pertença a uma grande nação foi alimentado com o objetivo de manter a unidade nacional e como condição fundamental para a construção da nova ordem que levaria o país à modernidade. Dessa forma, na atuação de professoras e professores depositavam-se boa parte das esperanças daqueles que queriam fazer do Brasil uma grande nação, num discurso adotado por diferentes setores da intelectualidade brasileira, de românticos a positivistas, e que as mulheres, que logo se tornaram a maioria entre os profissionais da educação, souberam bem aproveitar a seu favor para ampliar seus direitos ao acesso à educação e informação de qualidade.

O discurso ordenador dos positivistas mantinha a vocação feminina para a maternidade. Ele estendia o alcance da ação feminina para a educação formal e, portanto, a colocava fora do lar mas voltada ainda para a construção da nação. As professoras, por sua vez, ampliaram suas reivindicações de acesso a uma melhor educação, melhores condições de trabalho e melhor remuneração sob o argumento de que necessitavam de meios para melhor educar os futuros cidadãos brasileiros e, tão importante quanto, as futuras mães desses cidadãos, que por sua vez deveriam transmitir aos filhos, desde a mais tenra infância, os princípios morais e éticos esperados pelo Estado.

No conceito positivista, a classe dirigente seria formada pelos chamados homens de ciência, cabendo a ela também comandar o processo de mudança. As mulheres, enquanto mães e professoras, seriam o instrumento fundamental na propagação desse conjunto, pois a elas se atribuía a missão de educadoras.

Na base dessa construção, acha-se o perfil da mulher imaginado por
Comte e alimentado pela sua valorização como elemento propagador
do ideário patriótico, posição que lhe é devida, mercê de sua função
como reprodutora da espécie e transmissora dos princípios morais e
culturais às novas gerações.

Sob a influência das ideias positivistas, professoras como Leolinda, cooptadas pelo discurso hegemônico, passam a almejar o papel de construtoras dessa nação, incorpora-se a ela e, mais do que isso, engaja-se nessa proposta política atribuindo a si mesma uma parcela de responsabilidade na construção do novo Brasil. Para isso, colocou sua profissão, sua vida e sua família a serviço desse ideal, abrindo espaço entre as inúmeras barreiras que encontrava pela frente, procurando estender às populações indígenas o acesso à civilização, que - na opinião dela - só poderia ser alcançada através da educação.

Naquele final do século XIX em que as notícias e as fantasias a respeito da população indígena do Brasil cercavam o público, ora sob a forma de emblemas em celebrações, esculturas em praças públicas, romances, poesias e apresentações teatrais cheias de lirismo, ora em boatos aterrorizantes sobre os ataques dos índios bravios, Leolinda compreendeu que a educação e civilização desses povos era a sua missão.

49 DALTRO. Inícios do feminismo no Brasil, p.4.

50 TRINDADE, Etelvina de Castro. Clotildes e Marias: mulheres de Curitiba na Primeira República. Curitiba: Farol do Saber, 1996, p.178. 
No dia 9 de julho de 1896, entre várias notícias, o jornal O Paiz, divulgava o recebimento da visita de um grupo de índios vindos do estado de Goiás à sua redação, dando início a uma série de reportagens sobre o grupo de cherentes, chefiado pelo "capitão" Sepé, cuja visita à capital tinha como objetivo buscar apoio governamental para o aldeamento, sob a forma de tecidos para vestuário, ferramentas e sementes, além do envio de uma pessoa que pudesse assumir a educação dos índios por meio da abertura de uma escola na aldeia. A professora Leolinda visitou o jornal para conhecer os índios e ao final de sua visita decidiu partir com eles para formar uma escola para os índios nos sertões do Mato Grosso, invocando seu currículo profissional em defesa do seu direito de assumir a direção de pelo menos uma diretoria de índios ou de candidatar-se à disputa por um cargo eleitoral. No dia 27 de julho de 1896, o jornal O Paiz noticiava:

Sepé, Cumanacé, Dansom-Equequá, Debaqueró e Decapsicua, os valorosos representantes da longínqua tribo dos cherentes, feriram largo a imaginação meridional e a alma generosa de uma distinta professora fluminense, D. Leolinda de Figueiredo Daltro. Aos seus olhos de mulher de instrução, espírito aberto para as fantasias pelas leituras romanescas de viagens sertanejas por longes terras, a história da bela abnegação de Sepé e seus companheiros atravessando florestas e rios para vir até a capital do Brasil em busca da civilização da sua tribo, a história desses simpáticos índios, a organização exemplar de sua aldeia, a doçura de seus costumes verdadeiramente admiráveis, tudo isso tomou o caráter de uma sedução irresistível, impôs-se como uma sugestão fortíssima para acompanhá-los. ${ }^{51}$

Iniciava-se daquela maneira a aventura missionária de Leolinda. A seu favor, contava o número de cidadãos que havia formado, não apenas entre seus alunos e alunas regulares nos bancos de escolas do Distrito Federal, mas - o que poderia ser considerado ainda mais louvável - entre índios antes considerados selvagens.

\begin{abstract}
Numa luta ingente contra gratuitos e rancorosos inimigos, sem jamais ter recebido auxilio de quem quer que fosse, eduquei quinze índios; a todos ensinei a ler e escrever e tornei cidadãos da República, investindo-os nos seus direitos civis e políticos, conforme provam os votos a descoberto.

Tornei-os cidadãos úteis, pois que Ihes dei profissão, sendo dois ferreiros, dois carpinteiros, um pintor e um mecânico, empregando-se este na Estrada de Ferro Central do Brasil como ajustador de máquinas... ${ }^{52}$
\end{abstract}

Sob a sua ótica, e de acordo com os valores positivistas, Leolinda possuía todos os pré-requisitos para a função, e tentou provar isso através da publicação de documentos que seriam testemunhos em seu favor. Era boa mãe, era boa professora, era patriota e altruísta (trabalhou sem vencimentos pelo bem dos índios e dos alunos mais carentes). A opinião pública se dividiu: muitos acharam loucura, outros louvaram a iniciativa num debate contínuo que acompanharia a professora por décadas. Cerca de treze anos mais tarde, a própria Leolinda justificaria sua disposição em partir com os índios para Goiás como algo concernente ao seu espírito forte e habituado a todas as lutas, além da forte impressão que a leitura da obra O Selvagem ${ }^{53}$ causara em seu espírito, despertando nela a vontade de partir para os sertões do

51 “Missionária”, O Paiz, Rio de Janeiro, 27 jul. 1896, p.2.

52 DALTRO. Da catechese dos índios no Brasil, p.XXI.

53 COUTO DE MAGALHÃES, José Vieira. O selvagem. $2^{\text {a }}$ edição. Rio de Janeiro/São Paulo: Livraria Magalhães, 1876. 
Brasil a fim de estudar a cultura indígena, e do entusiasmo que teria se apoderado de seu espírito com a visita daquele grupo de índios ao Rio de Janeiro. ${ }^{54}$

Sobre o requerimento que apresentou ao governo solicitando uma licença de suas funções na Escola da Barra da Gávea por um período no qual iria se dedicar à catequese leiga no interior de Goiás, existem três versões: A primeira, dela própria, reproduzida pelo jornal O Paiz, de 17 de julho de 1896, em Da catechese dos índios..., na qual consta que ela teria reivindicado a "colocação de seus dois filhos menores no Colégio Militar, a conservação do seu lugar de professora nesta capital e pagamento dos vencimentos a que a cadeira dá direito" ${ }^{55}$; já no exemplar de $O$ Paiz, datado de 27 de julho de 1896, localizado durante esta pesquisa, encontrou-se o mesmo texto com algumas alterações, como o pedido de "conservação de seu lugar de professora nesta capital por dois anos e aumento em dobro dos pequenos vencimentos a que sua cadeira dá direito" ${ }^{, 66}$, sem qualquer referência a vagas no Colégio Militar para seus filhos. Nos registros da Secretaria de Instrução Pública, consta que a professora Leolinda requereu, em 8 de agosto de 1896, uma licença de três meses, com vencimentos, para montar uma escola de catequese para os índios de Goiás. ${ }^{57}$

Tais diferenças indicam a intenção da professora de, inicialmente, ausentarse por dois anos. Tendo sido persuadida, num determinado momento, de que não seria fácil conseguir uma licença tão prolongada, ela poderia ter optado por pedir uma licença mais curta na esperança de renová-la. Quanto aos vencimentos, a omissão do fato de que ela pretendia requerer um pagamento maior, em virtude de seu empenho pela civilização, deixa transparecer uma preocupação com a sua imagem pública, reforçando a imagem de mulher abnegada que se sacrifica em prol dos índios.

Com o apoio de várias pessoas ilustres, entre os quais o jornalista Quintino Bocaiúva e o diretor do Colégio Mackenzie de São Paulo (então chamado Escola Americana), que ofereceu vagas para dois filhos de Leolinda e ainda ajudou a angariar fundos para financiar a viagem, a professora partiu para a região do Xingu. A excursão era formada pela professora, o grupo de índios cherentes, seu filho mais velho, Alfredo Napoleão de Figueiredo, então com 19 anos, e o amigo Ezequiel Joaquim Pereira. ${ }^{58} \mathrm{~A}$ presença desses últimos deveriam conferir uma certa respeitabilidade à viagem da professora, que aparentemente não queria dar motivos a dúvidas quanto a sua reputação, por viajar sozinha entre um grupo de indígenas. ${ }^{59}$ Tais cuidados, porém, não a livraram de duras críticas, recebidas por meio da imprensa e por cartas de amigos e familiares. Meses depois de partir do Rio de Janeiro, já em Goiás, a professora teria recebido um telegrama do compadre Quintino Bocaiúva, aos cuidados de quem entregara a filha menor, de três anos: “De Goiás volte. Conselho não prorroga licença." 60 A maior parte das críticas que

54 DALTRO. Inícios do feminismo no Brasil.

55 DALTRO. Da catechese dos índios no Brasil, p.9.

56 O Paiz, Rio de Janeiro, 27 jul. 1896.

57 Livro de Instrução Pública. Docentes 1896-1899, fl.28. Arquivo Geral da Cidade do Rio de Janeiro.

58 José Ezequiel Pereira é apresentado na documentação examinada como: "um pretinho", "seu ex-escravo de nome Ezequiel...", ou ainda "um preto seu fiel amigo e ex-escravo". As entrevistas com a família, porém, apresentaram José Ezequiel como um tipo de agregado da família, que teria acompanhado D. Leolinda desde os primeiros anos no Rio de Janeiro. No Arquivo Nacional, foi encontrada documentação que confirma a versão familiar de que José Ezequiel era um ex-combatente da Guerra do Paraguai e de que sua pensão teria ajudado na manutenção da família de Leolinda quando esta se separou de seu marido. ROCHA, Elaine P. "Entre a Pena e a Espada”.

59 DALTRO. Da catechese dos índios no Brasil, p.237 e p.258.

60 DALTRO. Da catechese dos índios no Brasil, p.106. 
a professora sofreu condenavam o fato de uma mulher abandonar a família, a civilização, para viajar pelo sertão acompanhada por índios. Nessa época, Leolinda já havia se separado do segundo marido. Essa separação, nunca oficializada, Ihe valeu ainda mais críticas e uma oposição acirrada aos seus planos em geral.

Entre os opositores ao projeto civilizador de Leolinda estavam, segundo ela, religiosos capuchinhos, que criticavam as ideias positivistas e a educação leiga que ela tentava implementar nas aldeias. Segundo suas memórias, Leolinda teria visitado diferentes aldeamentos, detendo-se temporariamente em cada um deles, tentando desenvolver sua proposta de uma escola para índios. Porém, sem recursos materiais do governo e reconhecendo a grande demanda, Leolinda altera seus planos e volta para o Rio de Janeiro para solicitar sua nomeação como 'Diretora de Índios', o que lhe daria maior poder e recursos para seu projeto.

$\mathrm{Na}$ época, a República celebrava a bravura e os serviços do coronel Cândido Mariano Rondon, a quem Leolinda chegara a encontrar em suas andanças por Goiás. Rondon, depois promovido a marechal, era positivista e tinha a seu favor o apoio da grande maioria do governo. A professora não tinha o mesmo respaldo e era mulher, fato que ela reconheceu logo como empecilho para o reconhecimento de seu trabalho entre os índios e de seu projeto civilizador/educador.

Em seu retorno, Leolinda encontrou no Rio de Janeiro uma grande turbulência política causada pela crise econômica e que repercutia em todos os campos. O governo de Campos Sales (1898-1902) tentava conter a inflação, sanear os gastos públicos e equilibrar o orçamento fragilizado pela crise cafeeira. A crise se estendeu para além do governo de Sales e a classe trabalhadora sofria com a crise; desemprego, suspensão ou redução de salários eram comuns, situação que não excluía os professores, conforme lastimava Quintino Bocaiúva em 1903:

\footnotetext{
Virtualmente a situação é esta: temos professores e não temos escolas. O pessoal docente é numeroso, mas o exercício escolar restringe-se em toda a parte. A sorte do professorado é penosa e pungente, mas não é menos penosa, nem menos pungente a sorte daqueles que também por falta de recursos privam-se voluntaria ou forçadamente de alcançar para os seus filhos os benefícios da instrução. Em todo o estado, não careço esclarecer-vos, o empobrecimento é geral, porque nenhum trabalho é remunerador. ${ }^{61}$
}

A professora Leolinda de Figueiredo Daltro foi uma das muitas pessoas que se viram na penúria naquele período, conforme atesta um processo por dívida movido contra ela em janeiro de 1903. Segundo o processo, a professora recorreu a um agiota para empréstimo para o qual dera como garantia seus pagamentos mensais, mas não havia honrado o compromisso. Cabe lembrar que nesse período ela estava separada e era responsável pelo sustento de quatro de seus filhos, já que a mais velha estava casada. ${ }^{62}$

Em meio à crise, mais uma vez um grupo de indígenas chega à capital para reclamar proteção do governo federal contra a violência de fazendeiros e invasores de terras. Leolinda surge nos jornais, mais uma vez, como defensora dos índios os quais recolheu à sua casa em Cascadura. $O$ grande problema era que nesse tempo a professora morava nas dependências da escola onde ensinava. Denunciada, ela desafiou o chefe de Polícia que demandava a retirada dos índios daquele local,

61 Mensagem de Quintino Bocayuva à Assembleia Legislativa em 1903. Estado do Rio de Janeiro: Typographia do Jornal do Commercio, 1903, p.10-11.

62 Processo n. 1431 de 12/01/1903. Tribunal Cível e Criminal. Arquivo Nacional. 
gerando ainda mais polêmica, que se refletia nos jornais do Rio de Janeiro. Sem dinheiro, a professora utilizou os jornais e seus conhecidos para angariar fundos e remédios para tratar de 10 indígenas. Enquanto isso, ela os educava e continuava sua peregrinação pelas repartições públicas solicitando a nomeação referida para, mais uma vez, partir para os sertões e abrir uma escola para os índios. Em 1906, Leolinda causou mais um escândalo ao apresentar no Primeiro Congresso de Instrução Pública o seu projeto de catequese leiga para os índios, sob o comando de uma mulher.

De certa forma, a professora Leolinda virara uma referência para índios que chegavam ao Rio de Janeiro. Em 1909, ela tinha em sua casa - mais uma vez nas dependências de uma escola - 14 indígenas, que ela declarava como seus educandos e filhos adotivos, para evitar polêmicas quanto ao uso do prédio escolar. No mesmo ano ela enviou documento para o Congresso de Geografia para ser lido por um homem, já que a comissão organizadora se recusou a receber uma mulher, no qual trazia mapas e um relatório completo sobre as aldeias e seu trabalho como professora entre os índios de Goiás. ${ }^{63}$ Em 1910, quando o Serviço de Proteção aos Índios foi inaugurado, sob a direção do marechal Rondon, Leolinda não foi convidada. "Não fui lembrada na ocasião. Não mereci um convite, ainda que verbal, para a solenidade. Eu, que fora, de facto, a iniciadora do serviço de catequese no Brasil, conforme declarava o próprio ministro da Agricultura na presença de representantes da imprensa." 64

A partir de então, Leolinda sabia que sua luta deveria ser política. Ainda em 1910 ela fundou o Partido Republicano Feminil, um desdobramento da Junta Feminil pró-Hermes-Venceslau, fundada em 1909 para recrutar senhoras para apoiar a candidatura do marechal Hermes da Fonseca à Presidência da República. Com essa iniciativa, Leolinda buscava obter a desejada nomeação como Diretora de Índios, com o apoio de Orsina. Infelizmente o desejado cargo não se materializou, com a morte da primeira dama em 1912.

Gastei improficuamente os meus passos exibindo então todas as provas de meu trabalho. Reconheciam-no todos os presidentes da República que se iam sucedendo no governo, todas as autoridades com quem me entendia a respeito. Mas o reconhecimento dos meus serviços era uma simples manifestação de delicadeza. Logo que eu falava em obter um título oficial para prosseguir no meu serviço de catequese leiga, a resposta era a mesma, tanto de presidentes como de ministros e diretores: não havia verba... e não podia eu como mulher, ser para esse fim nomeada!... Havia é claro o reconhecimento do mérito em contraposição ao sexo!65

À parte de sua luta política, Leolinda mantinha sua atividade profissional. Em 1911 já havia fundado a Escola de Sciencias Artes e Profissões Orsina da Fonseca, que tinha por finalidade o ensino profissional para mulheres. Esse projeto recebeu apoio do governo federal e oferecia ensino gratuito a meninas e jovens, com um currículo que incluía o que na época se chamava matérias elementares e científicas, além de cursos profissionalizantes em fabricação de chapéus, flores artificiais, bordados, corte e costura e educação física, disciplina ainda considerada como tabu quando ministrada para mulheres.

63 "Memória". Annaes do Primeiro Congresso Brasileiro de Geografia v. IX. Rio de Janeiro: 1911. Acervo do IBGE, Rio de Janeiro.

64 Daltro, 1918, p.15.

65 Daltro, 1918, p.13. 
O governo do marechal Hermes da Fonseca dava continuidade ao debate sobre a militarização do país, que discutia as formas de recrutamento para o serviço militar. A campanha pela renovação do Exército nacional lançou, com a ajuda de Olavo Bilac, a ideia do "soldado-cidadão". A Primeira Guerra Mundial acirrou o debate e a campanha, com a adesão de vários intelectuais e da sociedade civil. Reorganiza-se a Confederação do Tiro de Guerra e voluntários passam a organizar Linhas de Tiro em diversas partes do país, na intenção de treinar os soldados. Além disso, havia uma pressão para que as escolas secundárias e as instituições de ensino superior incluíssem o treinamento militar em seu currículo. ${ }^{66}$

Enquanto a movimentação causada pela Primeira Guerra Mundial crescia na Europa e no norte da África, a Cruz Vermelha crescia na Europa com a entrada de mulheres no serviço de enfermagem, servindo mesmo em campos de batalha; no Brasil, a ainda recém-criada Cruz Vermelha publicava anúncios recrutando senhoras para o serviço voluntário como enfermeiras. Leolinda mais uma vez atendeu ao chamado e convidou um médico para dar curso de Enfermagem para suas alunas.

Em 1917, o país enfrentava nova crise econômica exacerbada pela epidemia de gripe espanhola e agitada pelas greves operárias. Paralelamente, outro fenômeno se registrava: o surgimento do movimento sufragista no mundo, que assombrava a sociedade brasileira. Várias mulheres na ocasião desafiaram a lei alistando-se como eleitoras: Leolinda de Figueiredo Daltro estava entre elas. ${ }^{67}$ Adicionalmente, ela se apresentou como candidata à intendência do Rio de Janeiro, concorrendo como candidata independente pelo Segundo Distrito, tendo recebido apenas 33 votos. $^{68}$

Naquele ano confuso, o Brasil debatia sobre a participação ativa na Primeira Guerra Mundial, após o ataque dos alemães na costa brasileira. Enquanto isso, na Europa, nos Estados Unidos e no Canadá, as sociedades se adaptavam às agruras da guerra. Mulheres eram recrutadas na Rússia e começavam a ser treinadas também na Inglaterra como soldados, primordialmente encarregadas de defender seus vilarejos na ausência de homens que estavam em campos de batalha. A Escola Orsina da Fonseca, seguindo o apelo dos jornais (que se dirigia à população masculina), abriu novos cursos para suas alunas: esgrima e tiro, criando a Linha de Tiro Rosa da Fonseca para suas alunas e, para escândalo geral, a professora Leolinda passou a levar suas alunas para práticas externas de táticas militares de batalha e de salvamento em pleno Campo de Santana, atraindo um grande público.

Em 1918, quando Berta Lutz ganhou fama com o seu discurso feminista, Leolinda tentou reivindicar para si o papel de precursora do feminismo, revitalizando o Partido Republicano Feminil e publicando um documento em que registrava sua trajetória: Início do Feminismo no Brasil: Subsídios para a História, que ela fez imprimir na gráfica de sua escola.

Sua morte, em 1935, foi de certa forma um reflexo de sua trajetória entre a modernidade e as reminiscências do atraso: Leolinda foi atropelada por um caminhão de bebidas quando saía do prédio da intendência do Rio de Janeiro. O centro da capital federal, ainda que modernizado, ainda refletia o lento desenvolvimento do país. Nas ruas, caminhões, bondes e carros dividiam espaço com carroças e

66 CARVALHO, José Murilo de. “As forças armadas na Primeira República: o poder desestabilizador”. In: FAUSTO, Boris (org). O Brasil Republicano. 2- Sociedade e instituições (1889-1930). $5^{\text {a }}$ edição. Rio de Janeiro: Bertrand, 1997 p.131-233.

67 COELHO, Mariana. Evolução do feminismo. Subsídios para a sua história. São Paulo: Imprensa Moderna, 1933.

68 Jornal do Brasil, Rio de Janeiro, 26 out. 1919, p.9. 
animais. A professora foi recolhida em meio à lama e estrume; no hospital contraiu uma infecção, talvez causada pela amputação de sua perna ou pela sujeira que penetrou em seus ferimentos.

A trajetória de Leolinda de Figueiredo Daltro reflete um momento importante da história do Brasil: a consolidação da República, a urbanização, o desenvolvimento de uma economia de mercado, da educação pública, das políticas indigenistas e do nascimento da luta das mulheres por direitos políticos. Na vida dessa mulher pertencente a uma classe média nascente percebe-se a grande influência do positivismo e de um exacerbado patriotismo, além da dedicação e orgulho pela sua profissão de professora.

Recebido em 22/07/2016 Aprovado em 19/11/2016 
